\title{
Portable Pulse Oximeter
}

\author{
I Putu Anna Andika, Triana Rahmawati, M. Ridha Mak'ruf \\ Department of Electromedical Engineering Poltekkes Kemenkes, Surabaya \\ Jl. Pucang Jajar Timur No. 10, Surabaya, 60245, Indonesia \\ annaandika04@gmail.com, triana.tekmed@gamil.com, m.reedha@gmail.com,
}

\begin{abstract}
Pulse oximeter is a tool to monitor oxygen saturation in the blood (arteries) and also a person's heart rate (BPM) without having to go through blood analysis. Lack or excess of oxygen in the blood will cause illness and disruption of the body's work. At a certain level, this disease can cause the risk of death. The purpose of this study was to develop a pulse oximeter. The design of this equipment uses the MAX30102 sensor. Then the sensor will start working and Arduino will do data processing. Data from the MAX30102 sensor entering the I2C pin is then displayed on the TFT LCD screen. This equipment is made portable to make it easier for users to do monitoring anytime and anywhere. This test is done by comparing modules with standard measuring instruments. From the results obtained, this equipment is worthy of use because, by Guidelines for Testing and Calibrating Medical Devices RI Ministry of Health in 2001, the maximum limit in fault tolerance was Pulse Oximeter $\pm 1 \%$.
\end{abstract}

\section{Keywords-Pulse Oximeter; Saturation Oksigen; Arduino; BPM; LCD TFT}

\section{INTRODUCTION}

Blood and heart are vital organs and have a very important role in a person's life. Blood is the body's transportation system that carries important substances needed by the body. Among substances contained in the blood also have an important role in meeting oxygen in the body. If the human body lacks or has excess oxygen, it will cause illness and disruption to other body's work systems[1]. While the heart functions to pump blood throughout the body, if the heart is not functioning properly, then a person cannot live normally. One way to find out the heart rate can be checked in the arteries. Heart rate usually refers to the amount of time needed by heart rate per unit of time generally known as BPM (Beat Per Minutes) [2].

The amount of one's heart rate, usually displayed per minute called beats per minute (BPM). The normal adult heart rate (17 years - 60 years) ranges from $60-100$ BPM [3] and oxygen levels in the blood in a person's body with normal oxygen saturation values are only $\geq 95 \%$. For SPO2 values, hemoglobin oxygen absorbs more infrared light, while deoxygenated hemoglobin absorbs more red light. (How to Design Peripheral Oxygen Saturation (SpO2) and Optical Heart Rate, 2015 in [4].

For an example of an instrument is Pulse Oximeter. Pulse oximeter only analyzes arteries and ignores other systems around the blood. The artery is the only thing that beats on the finger. So the oximeter is one method of using equipment to monitor the state of oxygen saturation in the blood (arteries) and also for monitoring a person's heart rate. To assist in the physical assessment of patients, without having to go through a blood test analysis [5].

This tool ever made by Elita Kartini in 2016 with the title "Pulse Fingertip Oximeter Shown PC (BPM)" but the tool is not portable or still require a voltage of PLN nets that cannot be carried everywhere [4], This tool has also been made by Septi
Kharunnisa 2017 entitled "Pulse Oximeter (SpO2) based IoT (Internet of Things)" but a tool created is also not equipped with heart rate parameters and still not portable or still require a voltage of PLN net[6], This tool has also been made by Isabella Ratna Dewi Mustika in 2018 with the title "SPO2 Portable" but a tool created is also not equipped with heart rate parameters (heart rate)[7].

Based on the results of the identification of the problems, the author will make equipment be entitled "Portable Pulse Oximeter" which is the development of equipment that has been made before. The development of equipment that will be used by the author to add Heart Rate parameters and also replace the previous system from the transmitter system to reflectance system and display the results in the form of numbers displayed on the TFT LCD (Thin Film Transistor).

\section{MATERIALS AND METHODS}

\section{A. Experimental Setup}

This study used ten subjects aged 21 and 22 years. Subjects were taken randomly and data collection was repeated 5 times.

\section{1) Materials and Tool}

This study uses the MAX30102 sensor to monitor oxygen saturation in the blood (SpO2) and heart rate (BPM). 2 resistors are used to pull up before entering the microcontroller. IC Atmega microcontroller 2560-16AU was used to process the data read by the sensor MAX30102. Nextion 2.4-inch TFT LCD as a display for displaying the value Spo2 and BPM. Using the 2 batteries as a power supply (UltraFire, Japan). Finger Pulse Oximeter with brand PUREMED type of OXY-777 was used as a means of comparison.

\section{2) Experiment}


In this study, researchers measured the value of spo 2 and heart rate from respondents who were randomly selected and the results were compared with standard.

\section{B. The Diagram Block}

By the time the power button is pressed then all the circuit will have voltage including the sensor if the sensor has been getting a voltage to signify the sensor is in a state ready or standby. Place your index finger over the sensor then press the Start button on the TFT LCD. After that the sensor will start working and begin processing the data is then processed by Atmega 2560-16AU. Data that have been identified in the form of percentage oxygen saturation and heart rate and will be issued or displayed on a TFT LCD screen.

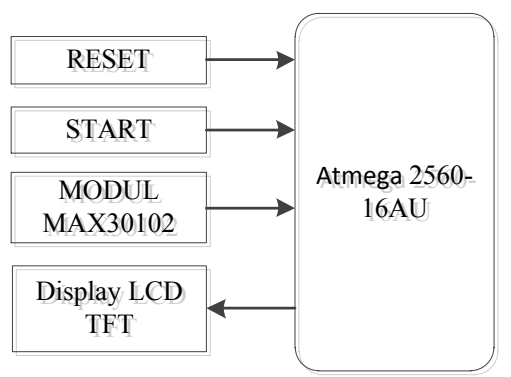

Fig. 1 The diagram block of the Pulse Oximeter

C. The Flowchart

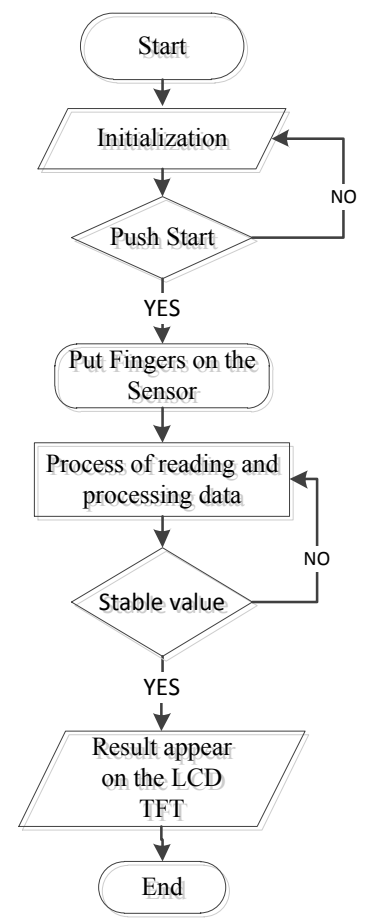

Fig. 2 The Flowchart of the Arduino Program

By the time the power button is pressed then all the circuit will have voltage including the sensor if the sensor has been getting a voltage means the sensor is in a state ready or standby. Place the index finger on the sensor then press the Start button on the TFT LCD. After that the sensor will start working and begin processing the data is then processed by Atmega 2560-16UA. Data that have been identified in the form of percentage oxygen saturation and heart rate and will be issued or displayed on a TFT LCD screen.

\section{Circuit}

\section{1) Circuit of microcontroller}

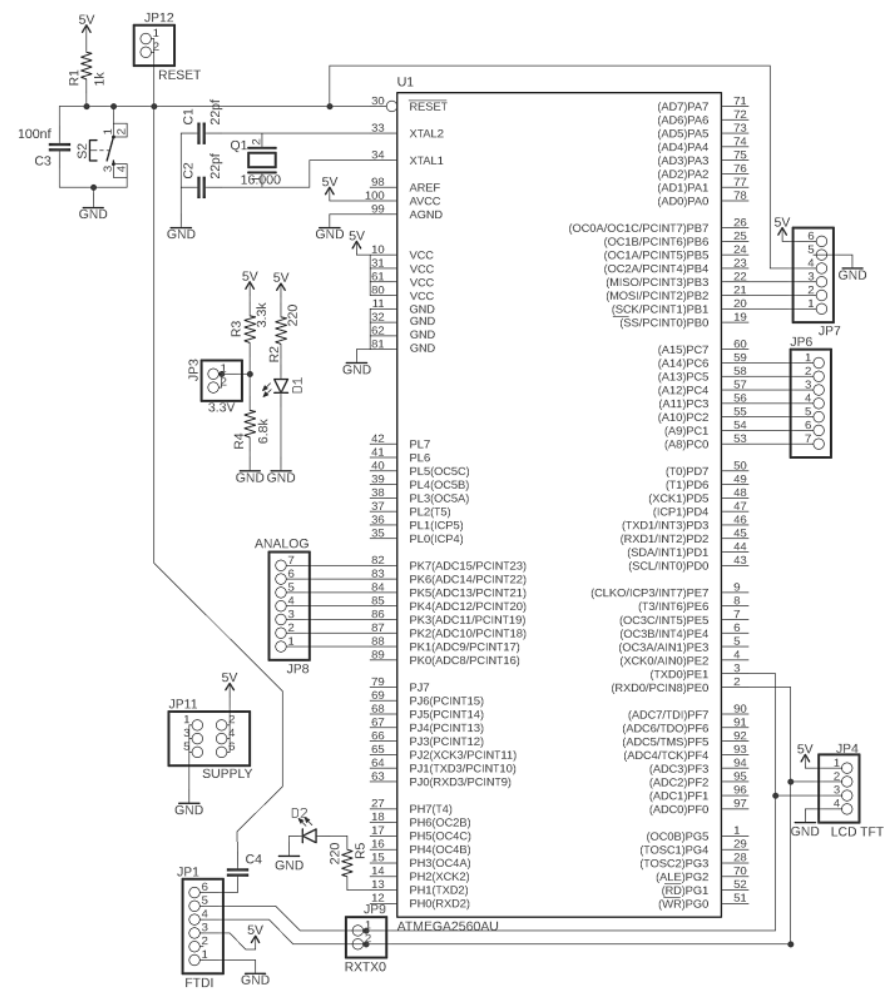

Fig. 3 Circuit of microcontroller

2) Pull-up resistor

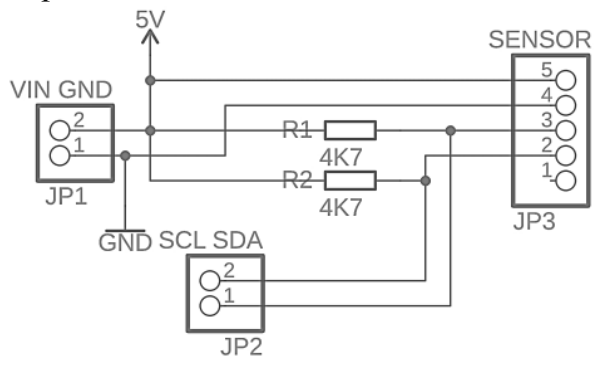

Fig. 4 Circuit of Pull-up resistor

The MAX30102 sensor has a digital value output. The value released is the ADC value that has been processed by the MAX30102 Sensor itself which is then processed by the microcontroller. before entering the microcontroller the value of the sensor is given a pull-up resistor. 


\section{RESULTS}

In this study, the Oximeter was tested by comparing it with a standard measuring instrument. The results show that the value of the oximeter with the value of a standard measuring instrument is feasible to use.
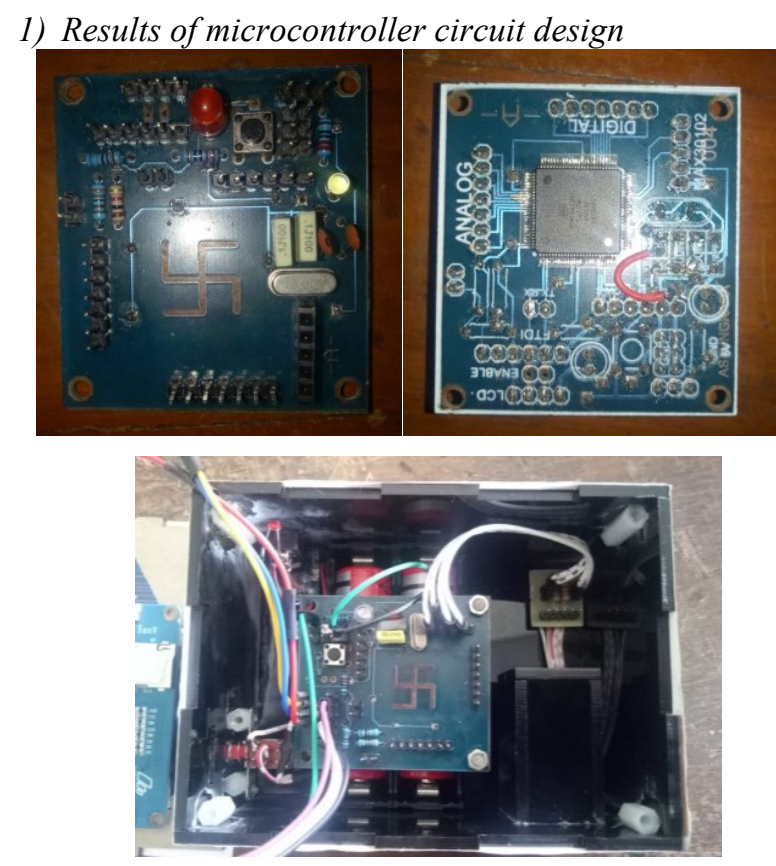

Fig. 5 Results of microcontroller circuit design

2) Pull-up resistor circuit design

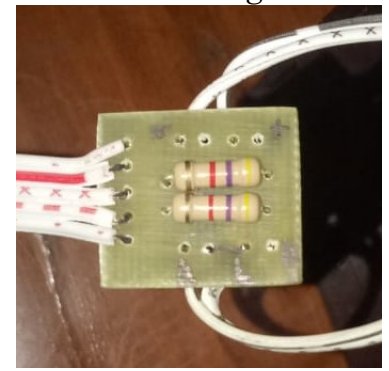

Fig. 6 Pull-up Resistor

3) Listing program for Stable and Difference Data

// Initialize the PulseOximeter instance
(!pox.begin ()$)$;
pox.setOnBeatDetectedCallback(onBeatDetected);
void loop ()
\{
pox.update ()$;$
if (millis ()$-$ tsLastReport $>$ REPORTING_PERIOD_MS)
\{
$/ /===========$ looking for stability $========$
if $(\operatorname{tanda}==0)\{$

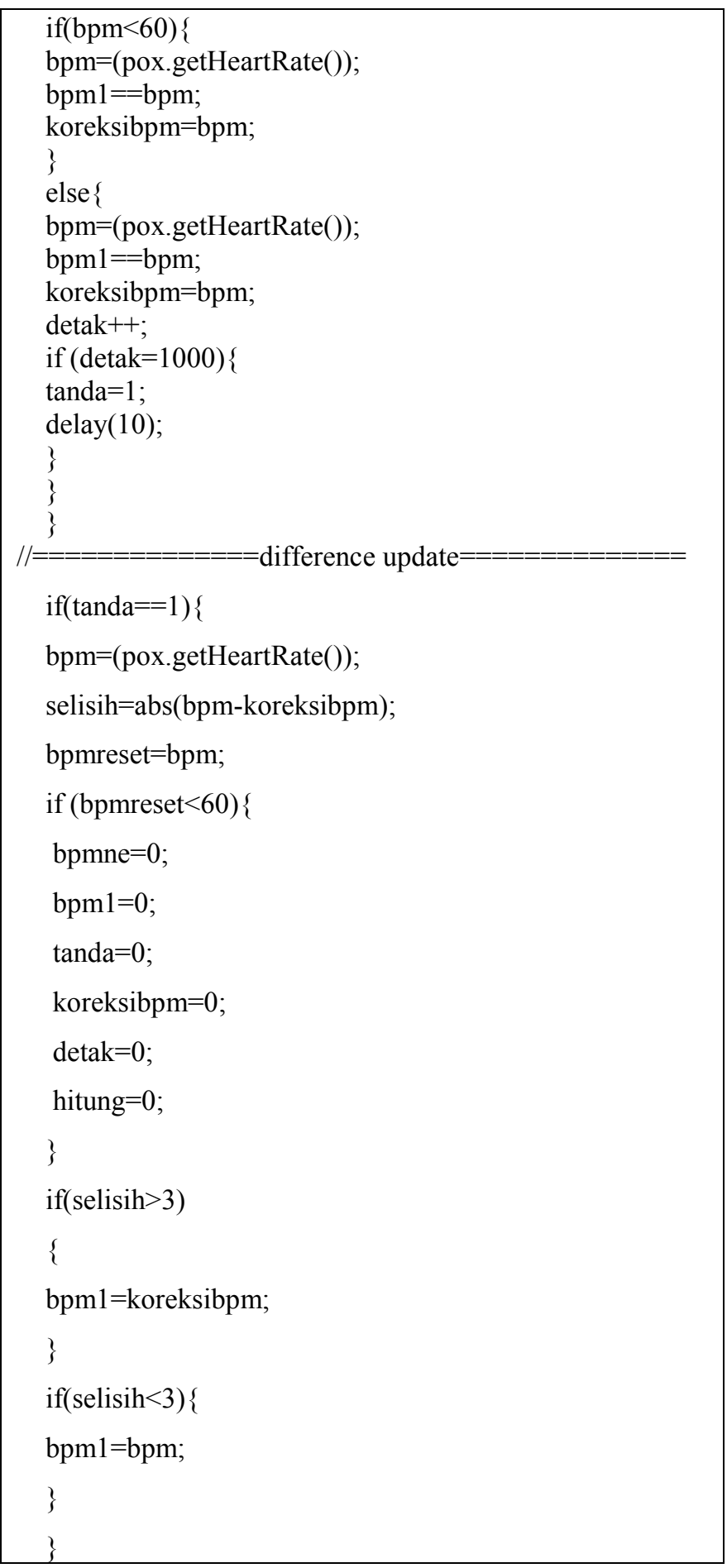

The above program is enabled to search the data is stable. Usually, the BPM value below 60 is still included not stable. Then functions to seek the differences of the data by another word for the data above 60 and when data BPM or BPM value change up to or down by a margin of 3 maximal the value displayed on the LCD is still the previous data. 


\section{4) Program initialization}

void $\operatorname{setup}()$

\{

Serial.begin(9600); // Start serial comunication at baud $=9600$

delay(500); // This dalay is just in case the nextion display didn't start yet, to be sure it will receive the following command.

Serial.print("baud=115200");

Serial.write(0xff); // We always have to send this three lines after each command sent to nextion.

Serial.write(0xff);

Serial.write(0xff);

Serial.end(); // End the serial comunication of baud $=9600$

Serial.begin(115200); // Start serial comunication at baud $=115200$

Serial.print("Initializing pulse oximeter..");

The above program is a program for TFT LCD and sensor initialization MAX30102 to be able to communicate with the microcontroller. TFT LCD with 9600 baud rate and sensor using a baud rate 115200 .

\section{5) Listing program for Display Functions}

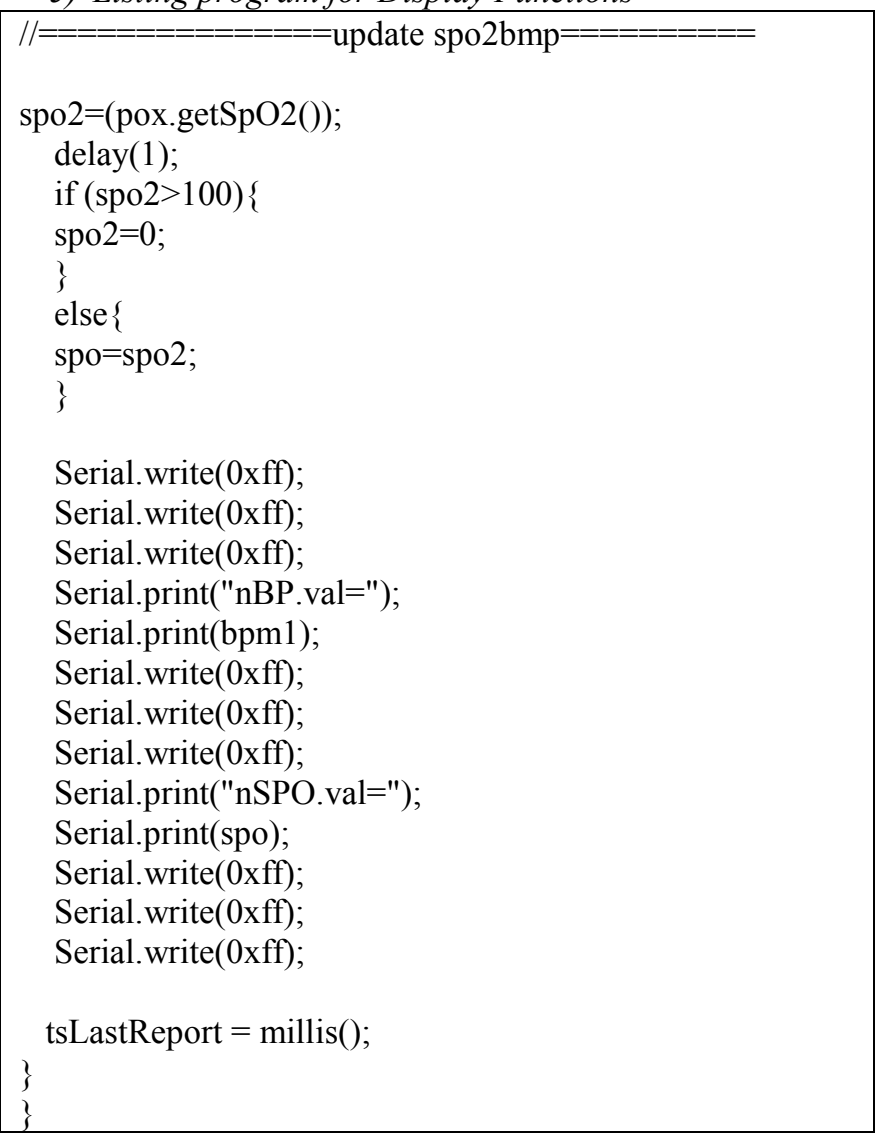

The above program is a command to display the data or value already dioalah by the previous program then communicated with TFT LCD that is data Spo2 with BPM.

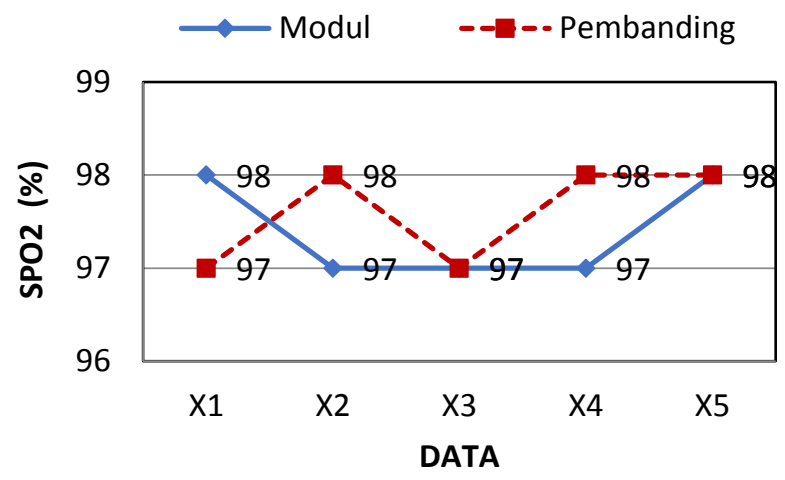

Fig. 7 The result of the reading between the comparison with the module (SPO2)

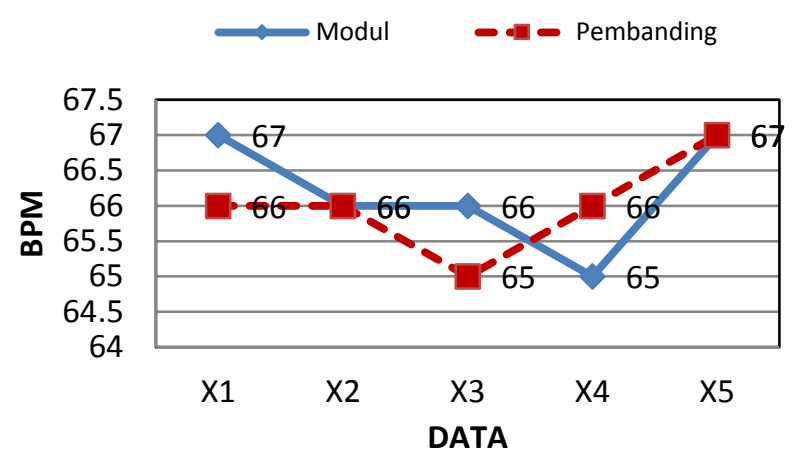

Fig. 8 The result of the reading between the comparison with the module (BPM)

6) The Error of BPM (Beats Per Minutes) value

TABLE I. THE ERROR OF MEASUREMENT FOR THE SPO2 PARAMETER BETWEEN THE DESIGN AND STANDARD UNIT (PULSE OXIMETRY).

\begin{tabular}{ccc}
\hline No & Subject & Error (\%) \\
\hline 1 & P1 & 0,20 \\
2 & P2 & 0,82 \\
3 & P3 & 0,82 \\
4 & P4 & 0,62 \\
5 & P5 & 0,61 \\
6 & P6 & 0,61 \\
7 & P7 & 0,82 \\
8 & P8 & 0,82 \\
9 & P9 & 0,82 \\
10 & P10 & 0,81 \\
\hline
\end{tabular}

7) The Error of BPM (Beats Per Minutes) value 
TABLE II. THE ERROR OF MEASUREMENT FOR THE BPM PARAMETER BETWEEN THE DESIGN AND STANDARD UNIT (PULSE OXIMETRY).

\begin{tabular}{ccc}
\hline No & Subject & Error $(\%)$ \\
\hline 1 & P1 & 0,30 \\
2 & P2 & 0,61 \\
3 & P3 & 0,84 \\
4 & P4 & 0,43 \\
5 & P5 & 0,66 \\
6 & P6 & 0,50 \\
7 & P7 & 0,77 \\
8 & P8 & 0,84 \\
9 & P9 & 0,84 \\
10 & P10 & 0,66 \\
\hline
\end{tabular}

\section{DISCUSSION}

In this study, the researchers measured the value of $\mathrm{SpO} 2$ and heart rate from 10 randomly selected adult respondents and the results were compared with standard measuring instruments. The spo 2 parameter produces an error value of $0.82 \%$ and for beat per minute parameters (BPM) produces an error value of $0.84 \%$. From the measurement results, this tool can work well and is suitable for use. But as for the weakness of this module that is when measuring if there is finger movement it will cause a large error value.

\section{Conclusion}

After making a Portable Pulse Oximeter module that uses the MAX30102 sensor with a minimum system using ATMega 2560-16AU displayed on a TFT LCD, it can be generally concluded that the Portable Pulse Oximeter module can be used as an appropriate medical device.

\section{REFERENCES}

[1] U. Salamah and K. Oksigen, "RANCANG BANGUN PULSE OXIMETRY MENGGUNAKAN ARDUINO SEBAGAI I . PENDAHULUAN Salah satu organ terpenting dalam tubuh manusia adalah darah . Darah merupakan sistem transportasi tubuh yang membawa zat- zat yang dibutuhkan oleh tubuh dan mengedarkannya ke selur," vol. 06, no. 02, 2016.

[2] G. W. Wohingati and A. Subari, "Alat Pengukur Detak Jantung Menggunakan Pulsesensor Berbasis Arduino Uno R3 Yang Diintegrasikan Dengan Bluetooth," J. Gema Teknol., vol. 17, no. 2, pp. 65-71, 2013.

[3] J. Hart, "Normal resting pulse rate ranges," J. Nurs. Educ. Pract., vol. 5, no. 8, pp. 95-98, 2015.

[4] E. Kartini et al., "FINGERSTIP PULSE OXYMETER TAMPIL PC ( BPM ) sensitif untuk mengetahui kadar oksigen dalam darah ( SPO2 ) dan dari akibat perbedaan kepekatan," pp. 1-8, 2015.

[5] A. A. Putra, "Oximetry Digital Berbasis," 2006.

[6] S. Khairunnisa, I. D. Gede, H. Wisana, I. Priyambada, C. Nugraha, and J. T. Elektromedik, "RANCANG BANGUN PULSE OXIMETER BERBASIS IOT ( INTERNET OF THINGS )," 2014.

[7] Isabella,. T. Elektromedik, "Spo2 portable," pp. 1-8, 2017. 